\title{
If analytic philosophy of religion is sick, can it be cured?
}

\author{
MOTI MIZRAHI \\ School of Arts and Communication, Florida Institute of Technology, Melbourne, FL 32901 USA \\ e-mail: mmizrahi@fit.edu
}

\begin{abstract}
In this paper, I argue that, if 'the overrepresentation of Christian theists in analytic philosophy of religion is unhealthy for the field, since they would be too much influenced by prior beliefs when evaluating religious arguments' (De Cruz and De Smedt (2016), 119), then a first step toward a potential remedy is this: analytic philosophers of religion need to restructure their analytical tasks. For one way to mitigate the effects of confirmation bias, which may be influencing how analytic philosophers of religion evaluate arguments in Analytical Philosophy of Religion (APR), is to consider other points of view. Applied to APR, this means considering religious beliefs, questions, and arguments couched in non-Christian terms. In this paper, I focus on Islam in particular. My aim is to show that Islam is a fertile ground of philosophical questions and arguments for analytic philosophers of religion to engage with. Engaging with questions and arguments couched in non-Christian terms would help make work in APR more diverse and inclusive of religions other than Christianity, which in turn would also be a first step toward attracting non-Christians to APR.
\end{abstract}

\section{Introduction}

Given that the 'world of analytic philosophy is an Anglo- and Eurocentric white male one' (Amico (2015), ix; (2017), 52), it should come as no surprise that Analytic Philosophy of Religion (henceforth, APR) is neither diverse nor inclusive. That is, the vast majority of published work in APR is concerned with Christianity and the Christian God, to the near exclusion of other monotheistic religions, such as Judaism and Islam, not to mention nonAbrahamic religions, such as Hinduism and Sikhism. As Nancy Frankenberry (2004, 5-6) puts it:

in the work of philosophers such as Richard Swinburne, Alvin Plantinga, William Alston, and D.Z. Phillips, philosophy of religion has been deployed in defense of the cogency of a standard form of Western monotheism, in the service of a conception of 'God' that is patriarchal, and in the vested interests of staunchly traditional forms of Christianity (see also Frankenberry (2018)).

Statistical evidence for this claim can be collected from PhilPapers, which 'is a comprehensive index and bibliography of philosophy maintained by the community of philosophers' (philpapers.org). There are currently (10/01/2018) 94,189 items in the 'Philosophy of Religion' topic on PhilPapers. The subcategory 'Specific Religions' does contain the following religions: Buddhism (3,455), Hinduism (139), Islam (3,127), Judaism (4,244), and Other Religions (16). But these count for a mere $11.64 \%$ of all the papers in the 'Philosophy of Religion' topic. As for Christianity, there are 6,724 papers on Christianity in the 'Specific Religions' subcategory. These search results are summarized in Table 1. 
Table 1. Numbers and percentages of papers in the 'Specific Religions' sub-categories compared to all papers in the 'Philosophy of Religion' topic on PhilPapers

\begin{tabular}{|l|l|l|l|}
\hline & Number of papers & $\begin{array}{l}\text { Percentage of } \\
\text { "Specific Religions" }\end{array}$ & $\begin{array}{l}\text { Percentage of } \\
\text { "Philosophy of } \\
\text { Religion" }\end{array}$ \\
\hline Christianity & 6,724 & $37.93 \%$ & $7.13 \%$ \\
\hline Judaism & 4,244 & $23.94 \%$ & $4.50 \%$ \\
\hline Buddhism & 3,455 & $19.49 \%$ & $3.66 \%$ \\
\hline Islam & 3,127 & $17.64 \%$ & $3.31 \%$ \\
\hline Hinduism & 139 & $0.78 \%$ & $0.14 \%$ \\
\hline Other Religions & 16 & $0.09 \%$ & $0.01 \%$ \\
\hline $\begin{array}{l}\text { Specific Religions, } \\
\text { Misc. }\end{array}$ & 20 & $0.11 \%$ & $0.02 \%$ \\
\hline TOTAL & 17,725 & $100 \%(17,725)$ & $100 \%(94,289)$ \\
\hline
\end{tabular}

Within the 'Philosophy of Religion' topic on PhilPapers, subcategories that might be considered purely APR, such as 'Arguments for Theism', 'Arguments against Theism', and 'Divine Attributes', contain even less items on religions other than Christianity. There are currently 1,725 items in the 'Arguments for Theism' subcategory, but only four of them $(0.23 \%)$ mention Islam, and only one of them $(0.05 \%)$ mentions Judaism. Similarly, there are currently 2,088 items in the 'Arguments against Theism' subcategory, but only ten of them $(0.47 \%)$ mention Islam, and only twelve of them $(0.57 \%)$ mention Judaism. Likewise, there are currently 1,976 items in the 'Divine Attributes' subcategory, but only six of them (0.30\%) mention Islam, and only thirteen of them $(0.65 \%)$ mention Judaism.

Additional statistical evidence for the lack of religious diversity in APR can be collected from other databases as well. ${ }^{1}$ For instance, I have looked at research articles published in one of the leading journals in the field of APR, namely, Religious Studies, which mention Christianity, Judaism, or Islam (i.e., one of the three, not all three), relative to the total number of research articles published in the journal Religious Studies between the years 1965 and 2012. ${ }^{2}$ I have used JSTOR Data for Research (dfr.jstor.org) to collect these data, which are summarized in Figure 1.

Figure 1. Proportions of research articles that mention Christianity, Judaism, or Islam (in all fields, including title, abstract, and full text) published in the journal Religious Studies from 1965 to 2012 (Source: JSTOR Data for Research). 


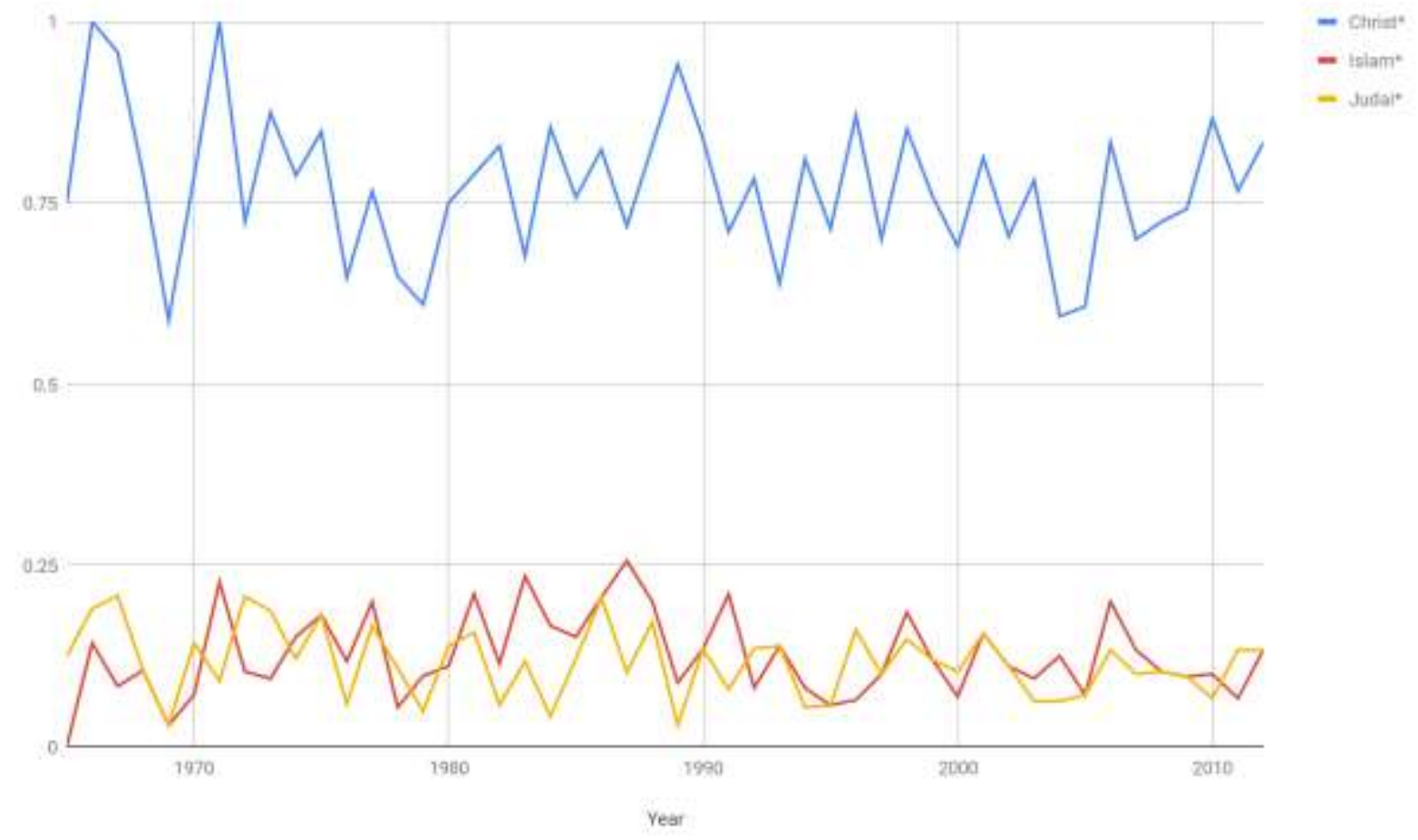

As we can see from Figure 1, compared to research articles that mention Judaism ${ }^{3}$ or those that mention Islam, ${ }^{4}$ research articles that mention Christianity ${ }^{5}$ clearly make up a significantly larger proportion of all the research articles published in Religious Studies between the years 1965 and 2012.

Similar results can be obtained by looking at data from another leading journal in the field of APR, namely, International Journal for Philosophy of Religion. As we can see from Figure 2, the data from International Journal for Philosophy of Religion corroborate the aforementioned results from Religions Studies. That is, compared to research articles that mention Judaism ${ }^{6}$ or those that mention Islam, ${ }^{7}$ research articles that mention Christianity ${ }^{8}$ clearly make up a significantly larger proportion of all the research articles published in International Journal for Philosophy of Religion between the years 1970 and 2014.

Figure 2. Proportions of research articles that mention Christianity, Judaism, or Islam (in all fields, including title, abstract, and full text) published in the journal International Journal for Philosophy of Religion from 1970 to 2014 (Source: JSTOR Data for Research). 


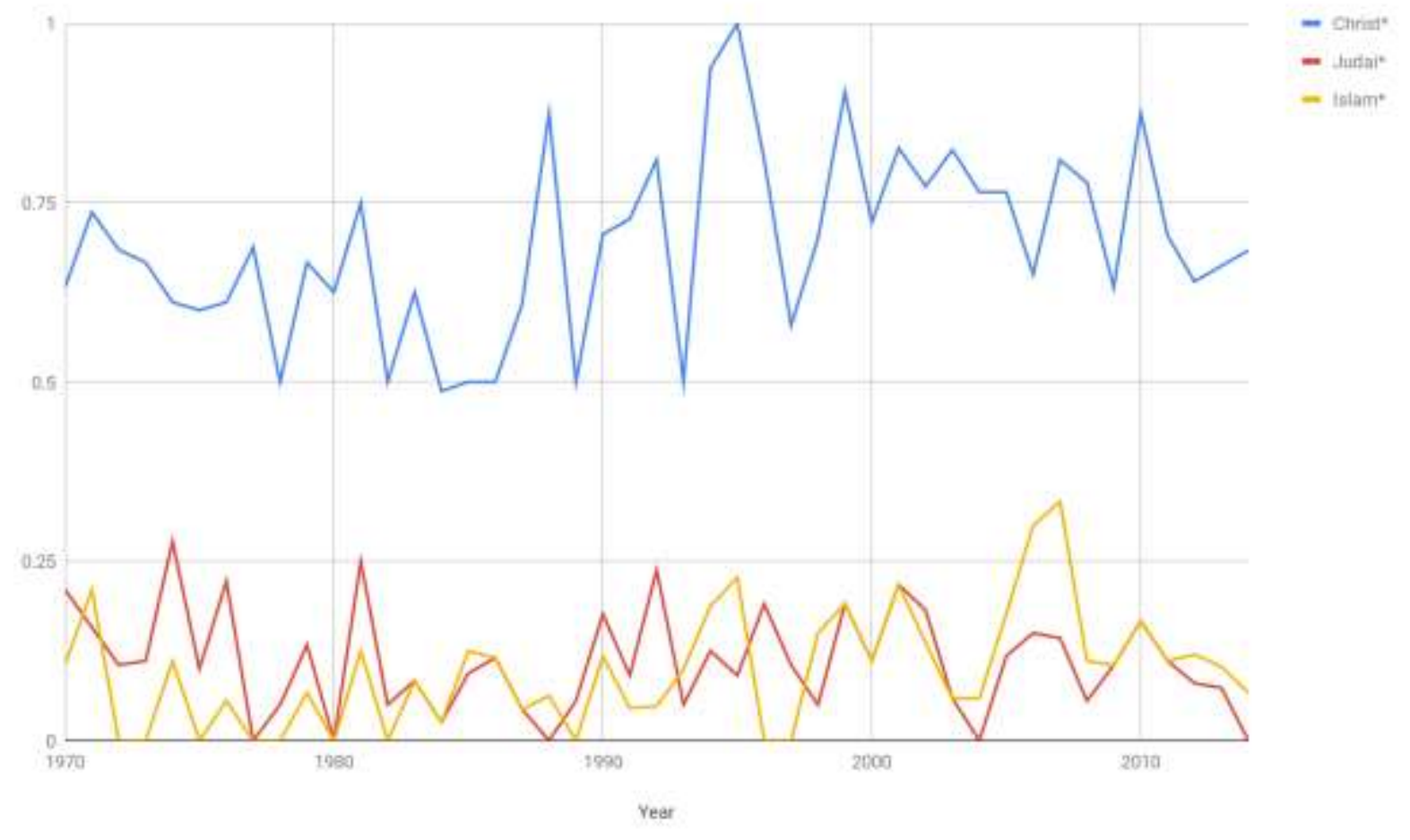

The aforementioned statistical data suggest that APR does not pay much attention to religions other than Christianity, even monotheistic religions other than Christianity, such as Judaism and Islam. This has led some philosophers to wonder how intellectually respectable APR really is (De Cruz (2013)). For instance, according to Paul Draper and Ryan Nichols (2013, 420):

Work in philosophy of religion exhibits at least four symptoms of poor health: it is too partisan, too polemical, too narrow in its focus, and too often evaluated using criteria that are theological or religious instead of philosophical. Our diagnosis is that, because of the emotional and psychosocial aspects of religion, many philosophers of religion suffer from cognitive biases and group influence (emphasis added).

Draper and Nichols (2013) are particularly concerned that work in APR exhibits confirmation bias. More explicitly, the fact that most analytic philosophers of religion are Christian theists is 'unhealthy' for the field because such philosophers are unable to evaluate arguments in APR without being influenced by their religious beliefs. ${ }^{9}$

Two independent surveys seem to support the claim that theists, in particular, Christian theists, are overrepresented in APR. The results of the PhilPapers Survey show that $72.3 \%$ of analytic philosophers of religion are theists (or lean toward theism), whereas only $11.7 \%$ of philosophers who are not analytic philosophers of religion accept or lean toward theism (Bourget and Chalmers (2014)). Like David Bourget and David Chalmers (2014), Helen De Cruz and Johan De Smedt (2016) have also found that 73\% of analytic philosophers of religion are theists. Moreover, De Cruz and De Smedt $(2016,130)$ have found some evidence in support of the hypothesis that 'the religious beliefs of philosophers of religion (who are, to a large extent, Christian theists) unduly influence their appraisal of religions arguments.' As De Cruz and De 
Smedt $(2016,131)$ report, such results have led other philosophers to say that APR is 'unhealthy' (see also Kraay (2013)). ${ }^{10}$

In addition to concerns about the overrepresentation of Christian theists in APR and cognitive biases, such as overconfidence and confirmation bias, others have expressed concerns about the relevance of APR to religion. For instance, Levine $(2000,89)$ argues that APR lacks 'vitality, relevance, and "seriousness".' Likewise, Trakakis $(2008,115)$ writes that:

To many religious believers, particularly those belonging to non-Western religious traditions, analytic philosophy of religion would appear to be a philosophy of anything but religion (emphasis in original).

Trakakis $(2000,89)$ argues that there is 'a disconnection in analytic philosophy of religion between the investigator and what they purport to be investigating' because APR is disconnected from 'the existential and lived dimension' of religion. Given that most analytic philosophers of religion are Christian theists, as the aforementioned studies show, the concern is that APR is disconnected from the lived experiences of practitioners of religions other than Christianity. ${ }^{11}$ In that respect, APR lacks in diversity and is not inclusive of religions other than Christianity. Assuming that '[d]iversity matters' (Hershock 2012, 1), the fact that APR is neither diverse nor inclusive of religions other than Christianity seems to be a problem.

If APR is indeed 'unhealthy' in the aforementioned ways, the question is whether it can be cured. Is there a remedy for APR's epistemic ills? This question is my focus in this paper. In other words, I take it for granted that APR is 'unhealthy' in the ways described above. I am interested in what can be done about it. Can APR be cured? What can be done to make work in APR more diverse and inclusive of religions other than Christianity? ${ }^{12}$

In what follows, then, I will propose what may be considered a first step toward remedying APR's epistemic ills. If 'the overrepresentation of Christian theists in analytic philosophy of religion is unhealthy for the field, since they would be too much influenced by prior beliefs when evaluating religious arguments' (De Cruz and De Smedt 2016, 119), then a potential remedy is this: analytic philosophers of religion need to restructure their analytical tasks. After all, one way to mitigate the effects of confirmation bias, which seems to influence how analytic philosophers of religion evaluate arguments in APR (De Cruz (2014)), is to consider other points of view (Wickens et al. (2013), 281). Applied to APR, this means considering religious beliefs, questions, and arguments couched in non-Christian terms. In this paper, I will focus on Islam in particular. My aim is to show that Islam is a fertile ground of philosophical questions and arguments for analytic philosophers of religion to engage with. Engaging with questions and arguments couched in non-Christian terms would help make work in APR more diverse and inclusive of religions other than Christianity, which in turn would also be a first step toward attracting non-Christians to APR.

Analytic philosophy of Islam

Granted that APR is 'unhealthy' insofar as Christian theists are overrepresented in APR, which is problematic because of cognitive biases, such as overconfidence and confirmation bias, and that 
work in APR is lacking in religious diversity and is not inclusive of religions other than Christianity, the question is how APR can be cured. In this section, I will propose what I take to be a first step toward restoring APR's epistemic health. There may be other remedies for APR's epistemic ills. So I do not pretend to claim that my proposal is the only way to deal with the aforementioned concerns about APR. But I do think that it is a promising way to deal with those problems, especially if our goal is to make work in APR more diverse and inclusive of religions other than Christianity. My proposal is grounded in the idea that a 'helpful approach to mitigating confirmation bias and overconfidence is to restructure the analytical task' (Bruce and Bennett (2008), 133).

Here is an example of how to restructure an analytical task, which is likely to be an example that most readers of this journal will be familiar with. If a professor wants to encourage active learning in the classroom, she might have students take sides on a controversial issue and argue for the side they agree with. But then, in order to have students develop a nuanced understanding of the controversial issue in question, she would make them switch sides; that is, argue for the view they do not agree with. This classroom activity is sometimes called 'pairs to squares', which is a variation on 'think-pair-share' (Gilton (2016), 36). In doing so, professors restructure the analytical task for their students in at least two important ways: (a) by asking them to look at a controversial issue from a perspective that is unfamiliar to them, thereby encouraging them to think in new terms, and (b) by asking them to argue for, rather than against, a view they disagree with, thereby encouraging them to reason from assumptions that they do not accept and draw inferences that they would otherwise not draw. ${ }^{13}$

As far as APR is concerned, to restructure the analytical task is to consider beliefs, questions, puzzles, problems, and arguments from a viewpoint that is not one's own. Accordingly, if most analytic philosophers of religion are indeed Christian theists, we could restructure the analytical task of APR by having analytic philosophers of religion engage with philosophical questions that arise in the context of religions other than Christianity when they write articles or teach courses in APR. As mentioned above, my focus in this paper is Islam, but I think that the same approach can be taken with respect to other non-Christian religions. ${ }^{14}$ In what follows, then, I will mention some of these philosophical questions in order to show that Islam is a fruitful area of research for analytic philosophers of religion. To be clear, my claim is not that these are new questions and arguments in APR. Rather, my claim is that these questions and arguments are couched in terms of a religion other than Christianity, and as such provide ways 'to restructure the analytical task (Bruce and Bennett (2008), 133) of APR, and thereby help address the aforementioned concerns about the overrepresentation of Christian theists, the lack of religious diversity and almost exclusive focus on Christian theism in APR's published work, and the threat of cognitive biases in APR. Such a restructuring of the analytical task is a helpful approach to mitigating cognitive biases, particularly confirmation bias and overconfidence, because it 'is aimed at challenging the mindsets that induce confirmation bias and exaggerate confidence' (Bruce and Bennett (2008), 133).

It is also important to mention at this point, as an anonymous reviewer helpfully pointed out, that some philosophical problems, questions, and arguments may be irreducibly particular, i.e., they may arise only within the context of a specific religious tradition. An example of this might be the concept of the Trinity, which seems to raise conceptual questions only within the context of 
Christianity, but not in the context of Islam, where the strict principle of the oneness of God holds. Nevertheless, in what follows, I do hope to show that there are instances in which the sort of problems, questions, and arguments typically discussed by analytic philosophers of religion can be restructured and couched in non-Christian terms. If analytical philosophers of religion were to take the problems, questions, and arguments they typically discuss in their scholarly work and in their APR classes, reformulate them in non-Christian terms (e.g., Islamic), and engage with them when they write papers or teach classes on APR, then the field of APR would take a significant step toward remedying its epistemic ills, or so I propose.

\section{The Shahada and the divine attributes}

Of the Pillars of Islam, the first is the Shahada (or declaration of faith): 'There is no deity but God, and Muhammad is the Messenger of God' (Alavi (2007), 8). The Shahada implies that the Prophet Muhammad has a unique status in Islam. Indeed, to suggest that God 'could create thousands of new worlds and Muhammads' (Qasmi (2014), 198), as Shah Ismail did, can get one denounced as an infidel and charged with apostasy for 'insulting the holy Prophet' (Jalal (2008), 81). Nevertheless, for present purposes, this contentious claim suggests a way to restructure the analytical task of APR. Here is how.

God is supposed to be omnipotent or all-powerful (Qur'an 8:10). A familiar version of a paradox about God's omnipotence can be stated as follows: can God create a stone so heavy that He himself cannot move it? This question poses the following problem concerning God's omnipotence:

If we say that God can create such a stone, then it seems that there might be such a stone. And if there might be a stone too heavy for Him to lift, then He is evidently not omnipotent. But if we deny that God can create such a stone, we seem to have given up His omnipotence already. Both answers lead us to the same conclusion (Mavrodes (1963), 221).

More formally, the paradox can be stated as follows:

1. Either God can create a stone too heavy for Him to lift or He cannot.

2. If God can create a stone too heavy for Him to lift, then God is not omnipotent.

3. If God cannot create a stone too heavy for Him to lift, then He is not omnipotent. Therefore,

4. Either way, God is not omnipotent. ${ }^{15}$

Now, the aforementioned suggestion by Shah Ismail provides a way to restructure the analytical task of analytic philosophers of religion who are interested in thinking about God's omnipotence in non-Christian terms (and if diversity and inclusion matter, then they should be interested in doing so). For it points to the following dilemma. On the one hand, Shah Ismail seems to be correct in suggesting that, if God were omnipotent, then He would be able to create many Muhammads. Accordingly, if one wants to hold on to the idea of Muhammad's uniqueness, then one would have to conclude that God is not omnipotent. That is: 
1. If God is omnipotent, then God can create many Muhammads.

2. There can be only one Muhammad.

Therefore,

3. It is not the case that God is omnipotent.

On the other hand, if one wants to hold on to the idea that God is omnipotent, then one would have to give up on the idea of Muhammad's uniqueness. That is:

1. If God is omnipotent, then God can create many Muhammads.

2. God is omnipotent.

Therefore,

3. God can create a thousand Muhammads.

But it appears that one cannot have it both ways; that is the dilemma. To sum up:

1. Either God can create many Muhammads or He cannot.

2. If God can create many Muhammads, then Muhammad is not unique.

3. If God cannot create many Muhammads, then God is not omnipotent.

Therefore,

4. Either Muhammad is not unique or God is not omnipotent.

This, of course, is a variation on the familiar problem concerning God's omnipotence, but it is now restructured and couched in terms of the religion of Islam. By introducing the Islamic idea of Muhammad's uniqueness, the analytical task of philosophers of religion has been restructured insofar as the omnipotence paradox now takes the form of a dilemma between two seemingly incompatible ideas in Islam. Restructuring the analytical task of APR in this way, I submit, would go some way toward making work in APR more inclusive of religions other than Christianity, and thereby help in terms of reducing the threat of cognitive biases in APR. For, assuming that most analytic philosophers of religion are indeed Christian theists, this sort of restructuring would encourage scholars and teachers of APR to think in new terms, to reason from assumptions that they do not typically accept, and draw inferences that they would otherwise not draw. In other words, this sort of restructuring 'is aimed at challenging the mindsets that induce confirmation bias and exaggerate confidence' (Bruce and Bennett 2008, 133).

An additional dilemma concerning the Shahada has to do with another divine attribute, namely, omniscience. God is supposed to be omniscient or all-knowing (Qur'an 8:10). If God is omniscient, then He knows the future; that is, God has foreknowledge. But if God has foreknowledge, then how can we act freely? For God would know what we will do before we do it, which means that we cannot fail to do what God knows we will do. More formally, the problem of God's foreknowledge and human free action can be stated as follows (Wierenga (2017)):

1. If God has foreknowledge that $S$ will do $A$, then it is necessary that $S$ will do $A$.

2. If it is necessary that $S$ will do $A$, then $S$ is not free with respect to doing $A$.

Therefore, 
3. If God has foreknowledge that $S$ will do $A$, then $S$ is not free with respect to doing $A$.

Now, the Shahada provides a way to restructure the analytical task of analytic philosophers of religion who are interested in thinking about God's omniscience in non-Christian terms (and if diversity and inclusion matter, then they should be interested in doing so). For, in Islam, the declaration of faith must be made freely, since 'There is no compulsion in religion' (Qur'an 2:256) according to the Qur'an. If God has foreknowledge, however, then He knows whether one will accept Islam as one's faith or not, which means that one is not free to accept Islam as one's faith. The dilemma, then, can be stated as follows:

1. Either one's acceptance of Islam is a free act or it is not.

2. If one's acceptance of Islam is a free act, then God is not omniscient.

3. If one's acceptance of Islam is not a free act, then there is compulsion in religion.

Therefore,

4. Either God is not omniscient or there is compulsion in religion.

By introducing the Islamic idea that 'There is no compulsion in religion' (Qur'an 2:256), the analytical task of philosophers of religion has been restructured insofar as the problem of God's foreknowledge now takes the form of a dilemma between two seemingly incompatible ideas in Islam. Again, restructuring the analytical task of APR in this way, I submit, would go some way toward making work in APR more inclusive of religions other than Christianity, and thereby help in terms of reducing the threat of cognitive biases in APR.

A somewhat similar dilemma arises from the fact that, according to the Qur'an, believers must fear God (Qur'an 3:102). As Bruce Lawrence $(2015,48)$ explains, the Arabic word taqwa means 'pious fear of God.' But to make someone do something, such as declaring one's faith in God, out of fear seems to be a form of compulsion. For example, if a robber points a gun at me and tells me to give him my wallet, I will be forced to give him my wallet out of fear of death. Similarly, one who fears God seems to be forced to declare one's faith in God out of fear. So, if to make someone do something out of fear is a form of compulsion, then the idea that one must fear God seems to be at odds with the idea that the declaration of faith must be made freely, i.e., without compulsion.

These, then, are some of the ways in which the analytical tasks of APR, e.g., analyses of the divine attributes of omnipotence and omniscience, can be restructured in non-Christian terms, e.g., in terms of the Pillars of Islam, such as the Shahada, and the injunction against compulsion in religion. This list of philosophical dilemmas about the Shahada is not meant to be exhaustive. If there are other conceptual issues with respect to the Shahada, then they will only strengthen my suggestion that Islam is a fruitful area of research for analytic philosophers of religion. If we want to restructure the analytical task of APR, and thereby address the concerns about the overrepresentation of Christian theists, the lack of religious diversity, the almost exclusive focus on Christian theism, and the threat of cognitive biases in APR, then analytic philosophers of religion should engage with philosophical problems that arise in the context of a religion other than their own, such as the aforementioned dilemmas concerning the Shahada and the divine attributes of omnipotence and omniscience in Islam. At the very least, doing so would make 
work in APR more diverse and inclusive of religions other than Christianity, which in turn would be a first step toward attracting non-Christians to APR.

\section{Mecca and God's omnipresence}

In addition to the Shahada (or declaration of faith), another Pillar of Islam is the hajj (or the pilgrimage to Mecca). As Lawrence (2015, 12-13) explains:

The centerpiece of Muslim ritual is the Ka'ba, a cuboid building in Islam's most sacred mosque in Mecca. It houses a black stone, said to be a meteorite from heaven, which is linked to both Ishmael, the elder son of Abraham, and his mother, Hagar, Abraham's handmaid. Banished to Arabia, Ishmael and Hagar found solace at the site of the Ka'ba and sustenance from its environs, including the Well of Zamzam.

The $K a$ 'ba stone is the point of orientation (qibla) for both daily prayer (salat) and the circumambulation (tawaf), which is a key practice in the performance of the pilgrimage (hajj).

The hajj raises interesting conceptual issues when we take into consideration the fact that, in addition to being omnipotent or 'all-mighty' and omniscient or 'all-wise' (Qur'an 8:10), God is also thought to be omnipresent or 'all-pervading' (Qur'an 2:115). For if God is indeed omnipresent, and so wherever one turns, God is there, there would seem to be no need to pray in a particular direction. Nevertheless, there is a verse in the Qur'an that talks about God's throne (Qur'an 7:54). The idea that God sits on a throne seems to imply that God has a body, and thus can occupy a particular spatial location. In that case, however, God would not be omnipresent when He is occupying a particular position in space.

It might seem as if the way out of this conceptual problem is to say that the Ka'ba stone is the point of orientation (qibla) for both daily prayer (salat) and the circumambulation (tawaf), not because God is believed to reside there, but rather because of its holiness. After all, if the $\mathrm{Ka}$ ' $b a$ stone is indeed 'a meteorite from heaven' (Lawrence (2015), 12), then it has a divine origin. But that would seem to run counter to the strict principle of the oneness of God (tawhid), and thus run the risk of turning the hajj into a form of idol worshiping. For if God is one (ahad) and single (wahid), as well as omnipresent, then no particular place can be holier (or more sacred) than any other. That is:

1. If God were omnipresent, then no particular place can be holier than any other.

2. But some places are holier than others (e.g., Mecca).

Therefore,

3. It is not the case that God is omnipresent.

On the other hand, if one wants to hold on to the idea that God is omnipresent, then it seems that one would have to give up on the theological significance of Mecca as a holy site and the $\mathrm{Ka}$ ' $b a$ stone as having a divine origin, and consequently the hajj itself. That is:

1. If God were omnipresent, then no particular place can be holier than any other.

2. God is omnipresent. 
Therefore,

3. No particular place (including Mecca) can be holier than any other.

Like the dilemma concerning God's omnipotence and Muhammad's uniqueness, this dilemma suggests that, if God is omnipresent, then no particular thing (e.g., the $\mathrm{Ka}$ 'ba) or place (e.g., Mecca) can be holier (or more sacred) than any other. The dilemma, then, can be stated as follows:

1. Either Mecca is a holy place or it is not.

2. If Mecca is a holy place, then God is not omnipresent.

3. If Mecca is not a holy place, then there is no need to pray in the direction of Mecca (or make a pilgrimage to Mecca).

Therefore,

4. Either God is not omnipresent or there is no need to pray in the direction of Mecca (or make a pilgrimage to Mecca).

By introducing the Islamic idea of the hajj, the analytical task of philosophers of religion has been restructured insofar as the problem of God's omnipresence ${ }^{16}$ now takes the form of a dilemma between two seemingly incompatible ideas in Islam. Again, assuming that most analytic philosophers of religion are indeed Christian theists, this sort of restructuring would encourage scholars and teachers of APR to think in new terms, to reason from assumptions that they do not accept, and to draw inferences that they would otherwise not draw. In other words, this sort of restructuring 'is aimed at challenging the mindsets that induce confirmation bias and exaggerate confidence' (Bruce and Bennett 2008, 133).

These, then, are some ways in which the analytical tasks of APR, e.g., analyses of the divine attribute of omnipresence, can be restructured in non-Christian terms, e.g., in terms of the Pillars of Islam, such as the hajj, and the holiness of Mecca. Again, this list of philosophical questions about the hajj is not meant to be exhaustive. If we want to restructure the analytical task of APR in order to mitigate the effects of confirmation bias, and thereby address the concerns about the overrepresentation of Christian theists, the lack of religious diversity, the almost exclusive focus on Christian theism, and the threat of cognitive biases in APR, then analytic philosophers of religion should engage with philosophical questions that arise in the context of a religion other than their own, such as the aforementioned questions concerning the hajj and God's omnipresence. At the very least, doing so would make work in APR more diverse and inclusive of religions other than Christianity, which in turn would be a first step toward attracting nonChristians to APR.

\section{The Qur'an and the primacy of Arabic}

According to Shabbir Akhtar (2008, 134), 'Muslims regard the Quran as the unadulterated word of God' and 'a revelation directly from God' (Akhtar (2008), 119). Moreover, the 'Quran was infallibly dictated to the illiterate Muhammad by the arch-angel Gabriel; when completed, it became the final and definitive expression of God's moral and spiritual purpose for all humankind for all time' (Akhtar (2008), 119). These claims about the status of the Qur'an in Islam raise interesting philosophical questions for analytic philosophers of religion to consider. 
First, how can a finite document contain 'the final and definitive expression of God's moral and spiritual purpose for all humankind for all time' (Akhtar (2008), 119)? According to Taha Jabir Alalwani (2017, XI-XII):

God has rendered the Qur'an so complete that it contains the entire Islamic religion. It is the Qur'an that provides the explication of everything, while the Prophet's example provides a comprehensive demonstration of how to apply everything taught in the Qur'an (emphasis added).

In other words, the Qur'an is supposed to be 'logocentric' (Cornell (1999), 76). But how can a finite text provide 'the explication of everything'? Presumably, there are more things in heaven and earth than can be contained in a finite number of verses, to paraphrase Shakespeare.

Second, if 'the Quran [i]s the unadulterated word of God' (Akhtar (2008), 134) and 'a revelation directly from God' (Akhtar (2008), 119), then there would be no need for interpretations and commentaries. After all, being 'all-mighty' and 'all-wise' (Qur'an 8:10), God could have revealed the Qur'an in a language so clear and precise that it would require neither interpretation nor commentary. But, in fact, there are numerous interpretations and commentaries on the Qur'an. Moreover, interpreting and commenting on the Qur'an is made more complicated by the notion of 'abrogation', which is 'that some verses of the Qur'an restrict, modify or even nullify other verses' (McAuliffe (2006), 187). Presumably, there would be no need for abrogation if the Qur'an were 'the divine word [that] arouses knowledge of God in the human consciousness' (Cornell (1999), 76). After all, why would God withdraw previously revealed verses? Doing so implies that God somehow made a mistake, which seems inconsistent with the divine attributes of omnipotence and omniscience. ${ }^{17}$

Indeed, why did the archangel Gabriel dictate the Qur' an to the Prophet Muhammad in Arabic? Again, being 'all-mighty' and 'all-wise' (Qur'an 8:10), God could have made Gabriel dictate the Qur'an to Muhammad in a universal language that all human beings could understand. After all, the message of the Qur'an is supposed to be universal. As Lawrence (2017, xii) puts it:

The Arabic Qur'an [...] becomes more than law or guidance or even a sacred book; it is also disclosure of the Divine Will for all humankind in all places at all times. Arabic becomes not just one among many languages but the key index to salvation, prioritized over any other human language (emphasis added).

Rather than prioritize one language over all others, however, a universal message that is intended 'for all humankind in all places at all times' would be more easily transmitted and received by all human beings in a universal language that all humankind could understand. Being all-powerful and all-knowing, of course, God could have made the entire world one community united by one language (cf. Qur'an 5:48).

Having a universal language that could be understood by all would have helped in terms of addressing another philosophical question that arises from thinking about the primacy of Arabic in Islam as the 'language of salvation'. For there are followers of Islam who do not understand 
Arabic, even if they learn how to recite the Qur'an. In that case, when they recite the Shahada, but they do not understand its meaning, since they are not fluent in Arabic, is their profession of faith sincere? The story of Prince Darmakusuma raises this question (Noertjahajo (1974), 32-35). It is a story about the spreading of Islam in Java and a Javanese prince who has an amulet entwined in his hair, which prevents him from dying. When the Prince meets the legendary Wali Sanga, who are said to have brought Islam to Java, they are able to remove the amulet from his hair, and he is finally able to die after reciting the Arabic words inscribed on it. Those Arabic words are the Shahada. But, of course, Prince Darmakusuma did not understand what he was reciting before his death. So, was his 'profession of faith' a sincere one? Was his 'conversion' to Islam a genuine one?

Finally, there is the question about the authoritative status of the Qur'an. Sunnis and Shiites deal with this question somewhat differently. As Tayba Hassan Al Khalifa Sharif $(2005,134)$ explains:

For the Sunnis, the Quran is its own proof by virtue of its $i$ 'jaz (miraculous uniqueness). [...] For the Shiites, the proof of the verity of the Quran lies with the Prophet, hence ahl al-bait [i.e., people of the house] is central to Shiite belief and devotion (emphasis in original).

From the analytic perspective of APR, both approaches raise complex philosophical issues. First, on the Sunni view, how can the Qur'an be 'its own proof'? For to say that the verity of the Qur'an comes from the Qur'an itself seems circular. Second, if the Qur'an is a source of knowledge because it is 'miraculously unique', then, depending on what 'miraculous uniqueness' means, other religious texts may or may not have a claim to 'miraculous uniqueness' as well. In other words, if what makes the verses of the Qur'an true is the fact that the Qur'an is 'miraculously unique', then it seems that there are other religious texts that could satisfy this requirement for being a source of knowledge. For example, the Torah is believed to have been revealed to Moses by God on Mount Sinai. Does that count as 'miraculous uniqueness'? The answer to the latter question may be 'yes', which is why Jews and Christians are considered 'People of the Book' (Qur'an 29:46) in Islam, which is to say that they also have divinely revealed texts, yet the Qur'an is considered the final divine revelation. In that case, however, other religious texts that are considered sacred by some, but that Muslims would not accept as being genuine divine revelations, might satisfy the 'miraculous uniqueness' requirement. For example, Mormons believe that the Book of Mormon, which is the unaltered word of God, was revealed to Joseph Smith by Moroni, the Prophet Mormon's son, who has returned in 1823 as an angel to reveal the location of the golden plates on which the Book of Mormon was inscribed to Joseph Smith (Gutjahr (2012), 15). Does that count as 'miraculous uniqueness'?

On the Shiite view, the Prophet Muhammad makes the Qur'an a source of knowledge. But this requires that God revealed the Qur'an to the Prophet without any error. And how can we be sure of that? Perhaps the Prophet misunderstood God's message. After all, the Prophet is human, and thus capable of making mistakes. Perhaps the archangel Gabriel made mistakes while dictating the Qur'an to the Prophet. After all, unlike God, the archangel Gabriel is neither omnipotent nor omniscient. Perhaps there was an error somewhere in the transmission of the divine message from the archangel Gabriel to the Prophet. 
Indeed, the story of the 'Satanic verses' raises an interesting sceptical possibility with respect to the status of the Qur'an as divine revelation. According to Ebrahim Moosa $(2008,574)$ :

The story centers on the recitation of the Prophet Muhammad of a portion of revelation that gave his Meccan interlocutors the impression that he was endorsing their idols. "Those were the high flying cranes whose intercession is sought," he chanted. On hearing this, his Meccan foes understood the innuendo as his endorsement of their idols. Some time later the Prophet announced that the revelation was not an angelic inspiration, but a satanic one.

The story points to the sceptical possibility that even the verses of the Qur'an that are considered divine revelation might be 'Satanic verses'. For, if we know that the Qur'an is divine revelation, then we know that it is not a satanic inspiration mistakenly taken to be divine revelation. Since we do not know that the Qur'an is not a satanic revelation--for all we know, it could be--it follows that we do not know that the Qur'an is a genuine divine revelation. That is:

1. If we know that the Qur'an is divine revelation, then we know that it is not satanic verses mistakenly taken to be divine revelation.

2. For all we know, the Qur'an could be satanic verses mistakenly taken to be divine revelation.

Therefore,

3. We do not know that the Qur'an is divine revelation. ${ }^{18}$

These, then, are some of the philosophical questions that arise from considering the status of the Qur'an as the final divine revelation from the analytical perspective of APR. I think that they illustrate how recasting the analytical task can open up new avenues of fruitful research in APR, make work in APR more diverse and inclusive of religions other than Christianity, and thereby help mitigate cognitive biases. Given that this sort of restructuring 'is aimed at challenging the mindsets that induce confirmation bias and exaggerate confidence' (Bruce and Bennett 2008, 133), it can be a helpful approach to dealing with the threat of cognitive biases in APR. This list of philosophical questions about the status of the Qur'an is not meant to be exhaustive. The fact that there may be other conceptual issues with respect to the Qur'an only further backs up my suggestion that Islam is a fruitful area of research for analytic philosophers of religion. If we want to restructure the analytical task of APR in order to mitigate the effects of confirmation bias, as well as address the worry about lack of diversity in APR, analytic philosophers of religion should engage with philosophical questions that arise in the context of a religion other than their own, such as Islam. At the very least, doing so would make work in APR more diverse and inclusive of religions other than Christianity, which in turn would be a first step toward attracting non-Christians to APR.

Of course, analytic philosophers of religion may be reluctant or unwilling to restructure their analytical tasks in order to make APR more religiously diverse and inclusive, and in the process take steps toward mitigating some of the cognitive biases that seem to afflict work in the field. But that is beside the point. ${ }^{19}$ My proposal is about what analytic philosophers of religion should do, not what they want or do not want to do. Given that '[d]iversity matters' (Hershock (2012), 
1), making work in APR more religiously diverse and inclusive is something we should do, whether we want to or not. And if, in the process of making work in APR more religiously diverse and inclusive, we can remedy some of the epistemic ills that afflict it, all the better.

It might also be objected that restructuring the analytical task of APR, such that questions and arguments in APR are couched in terms of a religion other than Christianity (e.g., Islam), will not really cure' its epistemic ills. What would really help APR is to have fewer Christian theists, and more non-Christian theists, or even non-theists, do APR. It should be clear that none of the above precludes attracting (or attempting to attract) more non-Christians to APR. I will certainly not object to that. But, of course, a first step toward attracting non-Christian theists to APR is to show that work in APR can be about religions other than just Christianity, in much the same way that a first step toward attracting more women to philosophy is to show that women can be role models in philosophy, e.g., by including readings from women philosophers in course syllabi (Thompson et al. (2016)). As Demarest et al. $(2017,528)$ have recently found, 'feeling similar to the kinds of people who become philosophers' is the strongest predictor of taking more philosophy courses. In other words, if we want to attract more women to philosophy, we need to make sure that they can feel similar to, or can identify with, professional philosophers. As Demarest et al. (2017, 532-533) put it:

women who do not feel similar to professional philosophers [...] are not likely to go on to take additional courses. [...] Instructors who care about the retention of women should do what they can to show their women students how they are similar to professional philosophers.

Similarly, analytic philosophers of religion who care about attracting more non-Christian theists to APR, as they should if they care about the epistemic health of the field, should do what they can to show non-Christians how work in APR can have something in common with their personal backgrounds. For, as Demarest et al. $(2017,529)$ also point out, people need to be able to 'identify with professional philosophers along some dimension'. The dimension can be gender, race, ethnic and cultural background, and of course, religion.

In that respect, however, a few words of caution are in order. In order to make APR more religiously diverse and inclusive of religions other than Christianity, scholars and teachers of APR must become acquainted with religious traditions other than their own. As an anonymous reviewer points out, however, this raises a worry, especially as far as teaching APR is concerned. For instance, an analytic philosopher of religion who teaches the problem of omnipotence in Islamic context to a class of mostly Christian students might give the wrong impression that Christianity has better resources to deal with this problem. In order to avoid creating such wrong impressions, scholars and teachers of APR must discuss diverse religious traditions competently, comparing and contrasting them fairly as far as the traditional problems of APR are concerned. This will require analytic philosophers of religion to do more work, of course, but if I am right, it will be worth it insofar as remedying APR's epistemic ills is concerned.

\section{Conclusion}


In this paper, I have proposed a first step toward addressing the epistemic problems that afflict APR as a field. More explicitly, given that 'the overrepresentation of Christian theists in analytic philosophy of religion is unhealthy for the field, since they would be too much influenced by prior beliefs when evaluating religious arguments' (De Cruz and De Smedt (2016), 119), one potential remedy is for analytic philosophers of religion to restructure their analytical tasks. For, one way to mitigate the effects of confirmation bias, which may be influencing how analytic philosophers of religion evaluate arguments in APR, is 'to restructure the analytical task' (Bruce and Bennett (2008), 133). Applied to APR, this means considering religious beliefs, questions, problems, and arguments couched in non-Christian terms. This strategy is 'aimed at challenging the mindsets that induce confirmation bias and exaggerate confidence' (Bruce and Bennett (2008), 133). To that end, I have focused on Islam in particular, and I hope to have shown that it is a fertile ground of philosophical questions and arguments for analytic philosophers of religion to engage with. Engaging with questions and arguments couched in non-Christian terms, I submit, would help make work in APR more diverse and inclusive of religions other than Christianity, which in turn would be a first step toward attracting non-Christians to APR. ${ }^{20}$

\section{References}

AFSARUDDIN, A. (2015) Contemporary Issues in Islam (Edinburgh: Edinburgh University Press).

AKHTAR, S. (2008) The Quran and the Secular Mind: A Philosophy of Islam (London: Routledge).

ALALWANI, T. J. (2017) Reviving the Balance: The Authority of the Qur'an and the Status of the Sunnah, translated by Nancy Roberts (Washington: The International Institute of Islamic Thought).

ALAVI, K. D. (2007) 'Pillars of Religion and Faith', in V. J. Cornell (ed.) Voice of Islam: Voices of Tradition vol. I. (Westport, CT: Praeger), 5-42.

AMICO, R. P. (2015) Antiracist Teaching (New York: Taylor \& Francis).

AMICO, R. P. (2017) Exploring White Privilege (New York: Routledge).

BOURGET, D., and CHALMERS, D. J. (2014) 'What Do Philosophers Believe?' Philosophical Studies, 170, 465-500.

BRUCE, J. B., and BENNETT, M. (2008) 'Foreign Denial and Deception: Analytical Imperatives', in R. Z. George and J. B. Bruce (eds.) Analyzing Intelligence: Origins, Obstacles, and Innovations (Washington, DC: Georgetown University Press), 122-137.

CARROLL, T. D. (2016) 'The Problem of Relevance and the Future of Philosophy of Religion', Metaphilosophy, 47, 39-58. 
CORNELL, V. J. (1999) 'Fruit of the Tree of Knowledge: The Relationship between Faith and Practice in Islam', in J. L. Esposito (ed.) The Oxford History of Islam (New York: Oxford University Press), 63-106.

DE CRUZ, H. (2013) 'Has Analytic Philosophy of Religion Really Become Intellectually Respectable?’ New Apps: Arts, Politics, Philosophy, Science (30 August 2013), http://www.newappsblog.com/2013/08/has-analytic-philosophy-of-religion-really-becomeintellectually-respectable.html.

DE CRUZ, H. (2014) 'Cognitive Science of Religion and the Study of Theological Concepts', Topoi, 33, 487-497.

DE CRUZ, H. and DE SMEDT, J. (2016) 'How Do Philosophers Evaluate Natural Theological Arguments? An Experimental Philosophical Investigation', in H. De Cruz and R. Nichols (eds.) Advances in Religion, Cognitive Science, and Experimental Philosophy (New York:

Bloomsbury), 119-142.

DEMAREST, H., ROBERTSON, S., HAGGARD, M., MARTIN-SEAVER, M., and BICKEL, J. (2017) 'Similarity and Enjoyment: Predicting Continuation for Women in Philosophy', Analysis, 77, 525-541.

DRAPER, P., and NICHOLS, R. (2013) 'Diagnosing Bias in Philosophy of Religion', The Monist, 96, 420-446.

FRANKENBERRY, N. (2004) 'Feminist Approaches', in P. S. Anderson and B. Clack (eds.) Feminist Philosophy of Religion: Critical Readings (New York: Routledge), 3-27.

FRANKENBERRY, N. (2018) 'Feminist Philosophy of Religion', in E. N. Zalta (ed.) The Stanford Encyclopedia of Philosophy (Summer 2018 Edition), https://plato.stanford.edu/archives/sum2018/entries/feminist-religion/.

GILTON, D. L. (2016) Creating and Promoting Lifelong Learning in Public Libraries: Tools and Tips for Practitioners (Lanham: Rowman \& Littlefield).

GUTJAHR, P. C. (2012) The Book of Mormon: A Biography (Princeton, NJ: Princeton University Press).

HERSHOCK, P. D. (2012) Valuing Diversity: Buddhist Reflection on Realizing a More Equitable Global Future (Albany: State University of New York Press).

INMAN, R. D. (2017) 'Omnipresence and the Location of the Immaterial', Oxford Studies in Philosophy of Religion, 8, 168-206.

JALAL, A. (2008) Partisans of Allah: Jihad in South Asia (Cambridge, MA: Harvard University Press). 
KRAAY, J. K. (2013) 'Method and Madness in Contemporary Analytic Philosophy of Religion', Toronto Journal of Theology, 29, 245-264.

LAWRENCE, B. B. (2015) Who is Allah? (Chapel Hill: The University of North Carolina Press).

LAWRENCE, B. B. (2017) The Koran in English: A Biography (Princeton, NJ: Princeton University Press).

LEVINE, M. P. (2000) 'Contemporary Christian Analytic Philosophy of Religion: Biblical Fundamentalism, Terrible Solutions to a Horrible Problem, and Hearing God', International Journal for Philosophy of Religion, 48, 89-119.

MAVRODES, G. I. (1963) 'Some Puzzles Concerning Omnipotence', The Philosophical Review, 72, 221-223.

MCAULIFFE, J. D. (2006) 'The Tasks and Traditions of Interpretation', in J. D. McAuliffe (ed.) The Cambridge Companion to the Qur'an (New York: Cambridge University Press), 181-210.

MIZRAHI, M. (2012) 'Jewish Survival, Divine Supervision, and the Existence of God', Shofar: An Interdisciplinary Journal of Jewish Studies, 30, 100-112.

MIZRAHI, M. (2013) 'New Puzzles about Divine Attributes', European Journal for Philosophy of Religion, 5, 147-157.

MIZRAHI, M. (2014) 'The Problem of Natural Inequality: A New Problem of Evil', Philosophia, 42, 127-136.

MOOSA, E. (2008) 'Social Change', in A. Rippin (ed.) The Islamic World (New York: Routledge), 565-575.

NOERTJAHAJO, A. M. (1974) 'Matinya Raden Darmakusuma', in A. M. Noertjahajo (ed.) Cerita Rakyat Sekitar Wali Sanga, translated by Ronit Ricci. (Jakarta: Pradnya Paramita), 32-35.

NUZZO, R. (2015) 'How Scientists Fool Themselves--and How They Can Stop', Nature, 526, 182-185.

PLANTINGA, A. (1984) 'Advice to Christian Philosophers', Faith and Philosophy, 1, 253-271.

QASMI, U. A. (2014) The Ahmadis and the Politics of Religious Exclusion in Pakistan (New York: Anthem Press).

SHARIF, TAYBA HASSAN AL-KHALIFA. (2005) 'Sacred Narratives Linking Iraqi Shiite Women Across Time and Space', in miriam cooke and Bruce Lawrence (eds.) Muslim Networks from Hajj to Hip Hop (Chapel Hill: University of North Carolina Press), 132-154. 
THOMPSON, M., ADLEBERG, T., SIMS, S., and NAHMIAS, E. (2016) 'Why Do Women Leave Philosophy? Surveying Students at the Introductory Level', Philosophers' Imprint, 16, 136.

TRAKAKIS, N. (2008) The End of Philosophy of Religion (New York: Continuum).

WICKENS, C. D., HOLLANDS, J. G., BANBURY, S., and PARASURAMAN, R. (2013) Engineering Psychology and Human Performance $4^{\text {th }}$ Ed. (New York: Routledge).

WIERENGA, E. (2017) 'Omniscience', in E. N. Zalta (ed.) The Stanford Encyclopedia of Philosophy (Spring 2017 Edition), https://plato.stanford.edu/archives/spr2017/entries/omniscience.

WILDMAN, W. J. (2010) Religious Philosophy as Multidisciplinary Comparative Inquiry:
Envisioning a Future for the Philosophy of Religion (Albany: SUNY Press).

\section{Notes}

${ }^{1}$ To be clear, by 'religious diversity' here I mean the diversity of religions being discussed in the field of APR, not the diversity of the religious beliefs held by practitioners in the field. In this paper, I focus on the former (i.e., diversity of religions being discussed in APR) rather than the latter (i.e., diversity of religious faiths of practitioners in APR), although some argue that both are problems for the field of APR, as discussed below.

2 JSTOR Data for Research allows for truncation or 'wildcard searching', which is a search methodology that picks out variants of a term. By using 'Christ*', then, I can search for mentions of Christianity, since the JSTOR database will retrieve results that include every word that begins with 'Christ', such as 'Christianity', 'Christian', and the like. Similarly, I have used 'Islam*' to search for mentions of Islam and 'Judai*' to search for mentions of Judaism.

${ }^{3}$ The mean is 0.11 and the standard deviation is $0.04(\mathrm{n}=48)$.

${ }^{4}$ The mean is 0.12 and the standard deviation is $0.05(n=48)$.

5 The mean is 0.77 and the standard deviation is $0.09(n=48)$.

${ }^{6}$ The mean is 0.11 and the standard deviation is $0.07(n=45)$.

7 The mean is 0.09 and the standard deviation is $0.08(n=45)$.

8 The mean is 0.69 and the standard deviation is $0.12(n=45)$.

${ }^{9}$ See also Wesley Wildman (2010, xi) on 'undiagnosed or obstinate religious bias' and parochialism in APR. As Thomas Carroll $(2016,45)$ explains, the problem is 'that many philosophers of religion seek to find post hoc justifications for previously held views on the nature of ultimacy.'

${ }^{10}$ As an anonymous reviewer pointed out, it might be argued that APR is just as partisan as some other areas of philosophy. That is, one might think that, just as Christian theists are overrepresented in APR, feminist philosophers are overrepresented in feminist philosophy, philosophers of a particular ethnic background dominate philosophy of race, and so on. It is rather difficult to assess this objection, however, if we do not have data on philosophers who specialize in these areas. In APR, we know that there is a significant difference between specialists and nonspecialists with respect to the question concerning the existence of God (Bourget and Chalmers 2014, 483). To the best of my knowledge, we do not have similar data about feminist philosophy, philosophy of race, philosophy of disability, etc. Moreover, as the same anonymous reviewer also pointed out, there is an important difference between APR and feminist philosophy, philosophy of race, and philosophy of disability. These three fields concern the issues of socially marginalized groups, such as women, people of colour, and people with disabilities, whereas male Christian theists can hardly be said to be members of a socially marginalized group.

${ }^{11}$ Cf. Carroll (2016) on what he calls APR's 'problem of relevance.'

${ }^{12}$ Of course, I am not saying that there are no non-theists and/or non-Christian analytic philosophers of religion and the aforementioned data support no such claim. Rather, the issue is the underrepresentation of religions other than Christianity in published work in APR (i.e., in journal articles and books). Likewise, the 'cure' I am recommending in this paper is to make work in APR more diverse and inclusive of religions other than Christianity, not to make the 
profession of APR more inclusive of philosophers other than Christian thesis, although the latter might be something we would like to do as well (but that is beyond the scope of this paper).

${ }^{13}$ On the use of such debiasing techniques in research more generally, see Nuzzo (2015).

${ }^{14}$ See, for example, Mizrahi (2012).

${ }^{15}$ For more on the divine attributes and some puzzles associated with them, see Mizrahi (2013).

${ }^{16}$ How can an immaterial being like God be located at each and every place? See, e.g., Inman (2017).

${ }^{17}$ For more on the problem of abrogation, see Afsaruddin (2015), 190-192.

${ }^{18}$ Of course, the notions of Satan and 'Satanic verses' raise philosophical questions that are usually discussed under the heading 'Problem of Evil'. For a recent discussion of such problems, see Mizrahi (2014).

${ }^{19}$ One might get this impression from works such as Plantinga (1984).

${ }^{20} \mathrm{I}$ have worked on this paper while participating in a National Endowment for the Humanities (NEH) Summer Institute on Islam in Asia at the East-West Center of the University of Hawai'i at Manoa (June-July 2017). I am grateful to the co-directors, Peter Hershock and Nelly van Doorn-Harder, and all the participants for a rich and rewarding intellectual experience. I have presented an earlier version of this paper at the annual meeting of the Florida Philosophical Association (November 2017) and I thank the audience for helpful criticisms and suggestions. Lastly, I am also grateful to two anonymous reviewers of Religious Studies for helpful comments on earlier drafts of this paper. 